Int. J. Dev. Biol. 55: 619-625

doi: $10.1387 / \mathrm{ijdb} .103181 \mathrm{rm}$

\title{
Differentiation of steroid-producing cells during ovarian differentiation in the protogynous Malabar grouper, Epinephelus malabaricus
}

\author{
RYOSUKE MURATA ${ }^{*}, 1$, HIROFUMI KARIMATA ${ }^{2}$,YASUHISA KOBAYASHI ${ }^{1}$, RYO HORIGUCHI ${ }^{3}$, KAZUO KISHIMOTO ${ }^{4}$, \\ MOTOFUMI KIMURA ${ }^{4}$, TOHRU KOBAYASHI ${ }^{5}$, KIYOSHI SOYANO ${ }^{6}$ and MASARU NAKAMURA ${ }^{1,7}$
}

\begin{abstract}
${ }^{1}$ Sesoko Station, Tropical Biosphere Research Center, University of the Ryukyus, ${ }^{2}$ Okinawa Prefectural Department of Agriculture, Forestry and Fisheries, Fisheries Division, ${ }^{3}$ Laboratory of Reproductive Biology, National Institute for Basic Biology, ${ }^{4}$ Okinawa Prefectural Fisheries and Ocean Research Center Ishigaki Laboratory, ${ }^{5}$ Laboratory of Molecular Reproductive Biology, Institute for Environmental Sciences and Graduate School of Nutritional and Environmental Sciences, University of Shizuoka, ${ }^{6}$ Institute for East China Sea Research, Nagasaki University and 'Solution Oriented Research for Science Technology (SORST) Japan Science and Technology Corporation, Honcho Kawaguchi, Saitama, Japan
\end{abstract}

\begin{abstract}
To understand the mechanism of sex differentiation in the protogynous Malabar grouper Epinephelus malabaricus, we performed an immunohistochemical investigation of the expression of three steroidogenic enzymes, cholesterol-side-chain-cleavage enzyme (CYP11a), aromatase (CYP19a1a), and cytochrome P45011beta-hydroxylase (CYP11b), in the gonads during ovarian differentiation. Strong positive immunoreactivity against CYP11a, the key enzyme of steroidogenesis, and CYP19a1a which is essential for estrogen (17beta-estradiol) production, appeared first in the somatic cells surrounding gonial germ cells in undifferentiated gonads and throughout ovarian differentiation. However, positive immunoreactivity against CYP11b, which is important for androgen (11-ketotestosterone) production, first appeared in the cluster of somatic cells in the ovary tunica near the dorsal blood vessel after differentiation. CYP19a1a and CYP11b did not co-localize in any cells. These results indicate that there are two types of steroid-producing cells, estrogen-producing cells and androgen-producing cells, in the gonads of this fish, and they are distributed differently, suggesting that these cells are derived from different somatic cells. Estrogen-producing cells appeared prior to ovarian differentiation, while androgen-producing cells were first detected after ovarian differentiation.These results suggest that endogenous estrogen is involved in ovarian differentiation.
\end{abstract}

KEY WORDS: Steroid-producing cell, 17beta-estradiol, 11-ketotestosterone, Protogynous hermaphrodite, Grouper

Sex steroid hormones are well known as one of the most important regulators of sex determination and differentiation, gonadal development, gametogenesis, and sexual maturation in vertebrates. Generally, sex steroid hormones are produced in steroid-producing cells (SPCs), namely, Leydig cells in the testes and theca cells in the ovary (Magoffin 2005; Griswold et al., 2009). To understand the reproductive mechanisms and development of reproductive functions in vertebrates, it is essential to understand the origin, developmental processes and characteristics of SPCs. In mammals, there are many studies on the origin, differentiation, and regulation of SPCs in the gonads (Habert et al., 2001; Magoffin 2005; Schmahl et al., 2008; Griswold et al., 2009). In the lower vertebrates, however, little is known about SPCs.

Generally in teleost fish, Leydig cells in the testes are the major site of androgens production, while estrogen is synthesized in granulosa cells by aromatization of testosterone which is synthesized in theca cells in the ovary (Hoar et al., 1978; Kagawa et al., 1982; Nagahama et al., 1982). There are a few reports about the origin, morphological characteristics, distribution, and innervations of SPCs in the gonads of some gonochoristic fish, but the knowledge about the origin and development of SPCs are still lack in teleost fish (Nakamura et al., 1993, 1996; Nakamura and Nagahama 1985, 1989, 1993).

Groupers are suitable fish for aquaculture in tropical and subtropical areas because of their fast growth and excellent taste;

Abbreviations used in this paper: DPH, days post-hatching; E2, 17 beta-estradiol; SPCs, steroid-producing cells; 11KT, 11-ketotestosterone.

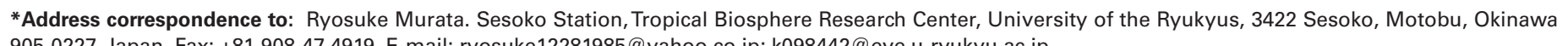
905-0227, Japan. Fax: +81-908-47-4919. E-mail: ryosuke12281985@yahoo.co.jp; k098442@eve.u-ryukyu.ac.jp 
however, most groupers are protogynous hermaphrodites, which cause a serious problem for aquaculture. After hatching, all individuals first function as female and then change their sex to male once they have grown to a certain size or reached a certain age (Smith 1965; Tan et al., 1974; Shapiro et al., 1987; Brusle et al., 1992; Shapiro et al., 1993; Sadovy et al., 1995; Bhandari et al., 2003). This makes it difficult to collect a parental male fish. The solution to this problem is to artificially control their sex using exogenous sex hormones. Generally, in the case of gonochoristic fish, the most effective time period for administration of exogenous sex hormones to induce artificial sex change is the period of gonadal sex differentiation (Nakamura et al., 1998). Basic information on gonadal sex differentiation in groupers is therefore essential for their successful aquaculture. In the case of groupers, however, there is little information on sex differentiation.

Groupers are not only suitable fish for aquaculture, but also good model fish for the study of sex change (Zhou and Gui 2010). Moreover, groupers are also a good model fish for sex differentiation and developmental biology, because they can be used as an initial all female population. Recently, we examined the morphological characteristics and timing of gonadal sex differentiation in the Malabar grouper Epinephelus malabaricus. Although it is clear that gonadal sex differentiation occurs around 47 to 74 days posthatching (DPH) in this fish (Murata et al., 2009), the physiological mechanisms of gonadal sex differentiation are unknown. Endogenous estrogen is known to play an important role in gonadal sex differentiation in several gonochoristic fish, but there are few reports in hermaphrodite fish (Hurk et al., 1982; Piferrer et al., 1994; Nakamura et al., 1998; Kitano et al., 2000; ljiri et al., 2008; Kobayashi et al., 2009).

To clarify the role of sex steroid hormones in gonadal sex differentiation in the protogynous Malabar grouper E. malabaricus, we investigated the appearance and development of SPCs by measuring the expression of several steroidogenic enzymes in the gonads during sex differentiation.

\section{Results}

\section{Specificity of A. japonica CYP11a, b and A. clarkii CYP19a1a}

Western blot analysis of $E$. malabaricus gonads revealed that $A$. japonicaCYP11 $a$ and $b$ antibody recognized a protein approximately of 57 and $40 \mathrm{kDa}$ respectively. A. clarkii CYP19a1a recognized a band of about $56 \mathrm{kDa}$ (Fig. 1).

\section{Expression of steroidogenic enzymes in the gonads during ovarian differentiation and early gonadal development}

The expression of three steroidogenic enzymes CYP11a, the key enzyme of steroidogenesis, CYP19a1a, which is essential for estrogen (17beta-estradiol; E2) production, and CYP11b, which is important for fish specific androgen (11-ketotestosterone; 11KT) production, in the gonads of Malabar grouper from 30 to $500 \mathrm{DPH}$ was analyzed by immunohistochemistry (Fig. 2). CYP11a was detected first in somatic cells surrounding germ cells in undifferentiated gonads at $30 \mathrm{DPH}$ (Fig. 2A). At the initiation of ovarian cavity formation, around 45 to $57 \mathrm{DPH}$, CYP11a was localized in somatic cells surrounding germ cells on the periphery of the presumptive ovarian cavity (Fig. 2D). A few of germ cells were distributed within the somatic tissue along the inner periphery of the ovarian cavity during ovarian cavity formation (Murata et al., 2009). Then, at the end of ovarian cavity formation, around $80 \mathrm{DPH}, \mathrm{CYP} 11 \mathrm{a}$ was localized in somatic cells surrounding germ cells in the side facing the ovarian cavity and in the cluster of somatic cells in the ovary tunica near blood vessels (Fig. 2G). Later, CYP11a-positive cells appeared in both areas; the area surrounding germ cell and ovary tunica area (Fig. 2 J,M). The first appearance of CYP19a1 a was also seen in the gonads at the undifferentiated stage and at the initiation of ovarian cavity formation (Fig. 2 B,E). However, CYP19a1a was later localized only to the somatic cells surrounding germ cells in the side facing the ovarian cavity (Fig. $2 \mathrm{H}, \mathrm{K}, \mathrm{N}$ ). CYP19a1apositive cells were elliptic in shape, like a fibroblast. We did not detect CYP11b in any somatic cells prior to ovarian differentiation (Fig. 2 C,F). Positive immunoreactivity against CYP11b was seen first at the end of ovarian cavity formation in the cluster of somatic cells near the blood vessel in the dorsal side of the ovary (Fig. 2I). Later, CYP11b-positive cells which were globular in shape, was expressed in the cluster of somatic cells in the ovary tunica near the blood vessels (Fig. 2 L,O).

\section{Localization of SPCs in the ovaries of the Malabar grouper}

To investigate the localization of SPCs in the ovaries of the Malabar grouper (130 DPH), we used double immunofluorescence staining (Fig. 3). CYP11a was detected in the somatic cells surrounding germ cells and in the cluster of somatic cells near the blood vessel (Fig. 3A), whereas CYP19a1a localized to somatic cells surrounding germ cells on the side facing the ovarian cavity (Fig. 3C). In contrast, CYP11b localized to somatic cells in the ovary tunica near the blood vessels (Fig. 3E). By performing

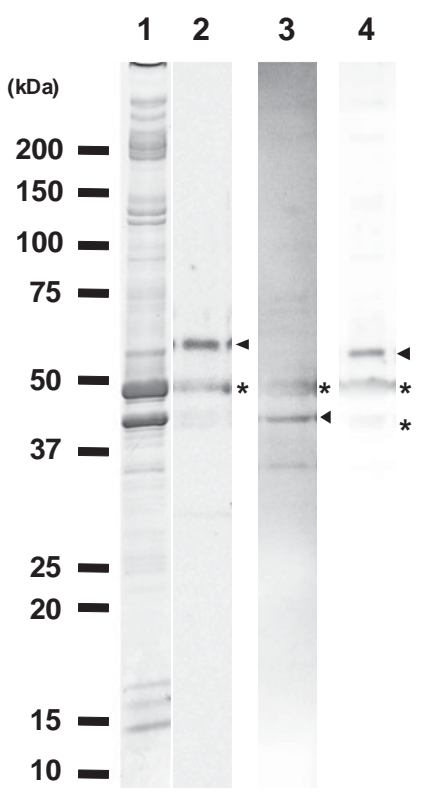

Fig. 1. Westernblot analysis of Epinephelus malabaricus gonadal proteins using anti-CYP11a, CYP11b and anti-CYP19a1a antiserum. Gonadal proteins from $50 \mathrm{mg}$ tissue were electrophoresed under denaturing conditions (10-20\% gradient gel). Separeted proteins were stained by CBBR (Lane 1) and immuno-stained with anti-CYP11a (lane 2), anti-CYP11 b (lane 3) and anti-CYP19a1a (lane 4) rabbit antiserum. Specific signals are indicated by arrowhead, and non-specific binding is indicated by asterisks on the right of each lane. The molecular masses of protein standards are indicated on the left. 

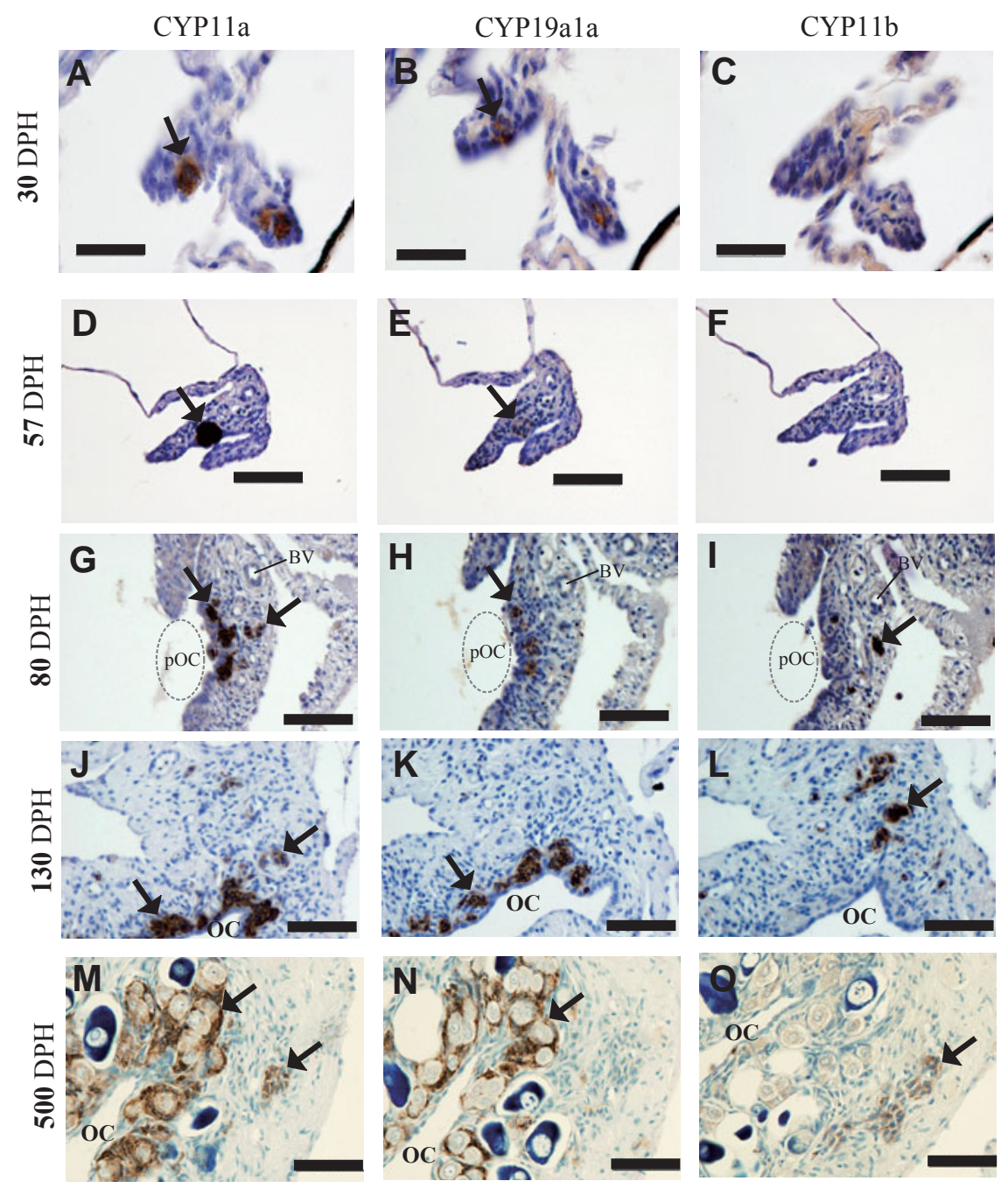

Fig. 2. Photomicrographs of gonadal sections of the Malabar grouper during ovarian differentiation and ovarian development. (A,D,G,J,M) Immunostaining with anti-CYP11a. $(\mathbf{B}, \mathbf{E}, \mathbf{H}, \mathbf{K}, \mathbf{N})$ Immunostaining with anti-CYP19a1a. (C,F,I,L,O) Immunostaining with anti-CYP11b. (A-C) Undifferentiated gonads at $30 \mathrm{DPH}$. Scale bar shows $20 \mu \mathrm{m}$. (D-F) The initiation of ovarian differentiation at $57 \mathrm{DPH}$. (G-I) The end of ovarian differentiation at $80 \mathrm{DPH}$. (J-L) Immature ovary at $130 \mathrm{DPH}$. (M-O) Immature ovary with perinucleolus stage oocytes at $500 \mathrm{DPH}$. Scale bar shows $50 \mu \mathrm{m}$. Arrow indicates positive immunoreactivity. BV: Blood vessel, pOC: Presumptive ovarian cavity, OC: Ovarian cavity.

double staining, CYP11a and CYP19a1a were seen to co-localize in the somatic cells surrounding germ cells on the side facing the ovarian cavity (Fig. 3B). Co-localization of CYP11a and CYP11b was also observed in the cluster of somatic cells in the ovary tunica near the blood vessels (Fig. 3D). However, no co-localization of CYP19a1a and CYP11b was seen in the gonads, suggesting that they are distributed in the somatic cells in different areas (Fig. 3F).

\section{Ultrastructure of SPCs}

We examined the ultrastructure of SPCs detected by specific antibodies against the steroidogenic enzymes CYP11a, CYP11b and CYP19a1a by transmission electron microscopy (TEM). CYP11aand CYP19a1a-positive cells had characteristics like fibroblasts (Fig. 4A). CYP11a- and CYP11b-positive cells exhibited a typical feature of SPCs, namely, many large mitochondria with tubular cristae and well-developed smooth endoplasmic reticulum (Fig. 4B). Schematic diagram of the appearance of two types of SPCs in the gonads during ovarian differentiation is shown in Fig. 6.

\section{Serum levels of E2 and 11KT during early go- nadal development}

The serum E2 and 11KT levels of the Malabar grouper from 45 to $500 \mathrm{DPH}$ were measured by ELISA (Fig. 5). E2 and 11KT were detected from the initiation of ovarian differentiation (45DPH) and during early ovarian development. Serum E2 levels were higher than serum $11 \mathrm{KT}$ levels throughout the testing period. We could not apply statistical analysis to the serum steroid levels during ovarian differentiation (i.e. ovarian cavity formation) because the samples were pooled due to a small size of fish. After ovarian differentiation (130 to $500 \mathrm{DPH})$, there were no significant differences in the serum E2 and $11 \mathrm{KT}$ levels.

\section{Discussion}

In this study, we demonstrated that there are two types of SPCs, namely, estrogen-producing cells and androgen-producing cells, derived from the somatic cells in distinct areas. We also showed that both endogenous estrogen and androgen were synthesized prior to ovarian differentiation, suggesting that they were involved in the process of ovarian differentiation and development in this fish.

\section{Origin of steroid-producing cells}

CYP19a1a is essential to the production of E2, while CYP11b is involved in the synthesis of the 11KT (Nagahama et al., 1982; Miller 1988; Miura et al., 1991; Kime 1993). In mammals, estrogens and androgens are synthesized by specialized endocrine cells: the Leydig cells are differentiated from mesenchymal-like stem cells in the testes and theca cells are derived from cuboidal granulose cells in the ovary (Habert et al., 2001; Magoffin et al., 2005). In the case of teleost fish, Leydig cells in the testes also are the major site of androgen (11KT) production, and estrogen (E2) is synthesized in granulosa cells in the ovary (Hoar et al., 1978; Kagawa et al., 1982; Nagahama et al., 1982; Kobayashi et al., 1998). However, there are only a few reports about the origin and development of SPCs in the testes and ovary (Nakamura and Nagahama 1985, 1989).

In the present study, to clarify the involvement of estrogen and androgen in the gonadal sex differentiation of protogynous fish, we used Malabar grouper as the model of this study, and three primary antibodies against steroidogenic enzymes; CYP11a, CYP11b and CYP19a1a. Western blot analysis revealed that the $A$. japonica Cyp11a, b and A. clarkiiCYP19a1 a antibodies specifically detected three proteins in female Malabar grouper E. malabaricus gonadal homogenates. A protein of approximately $57 \mathrm{kDa}$ was detected in the ovary by $A$. japonica CYP11a antibody and thus had a similar molecular weight to that of other known fish CYP11a proteins 

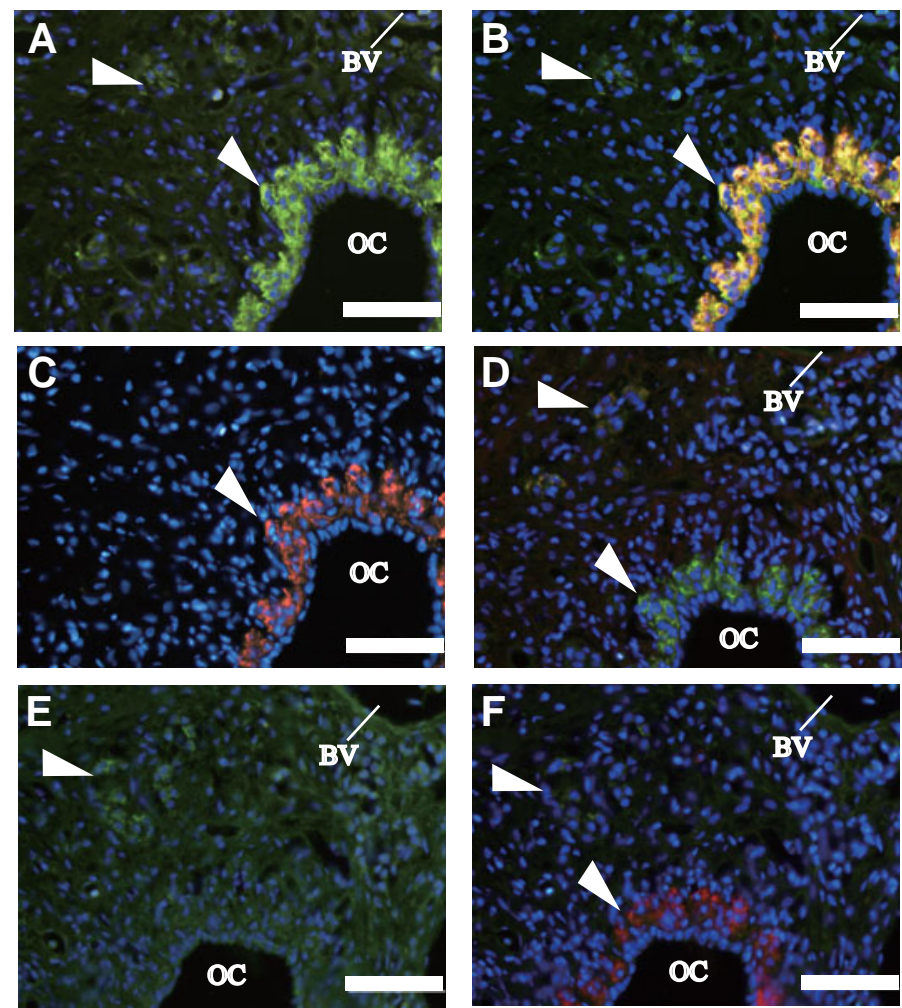

Fig. 3. Localization of steroid producing cells (SPCs) in the gonads of the Malabar grouper (130 DPH). (A) Single immunostaining with anti-CYP11a (green). (C) Single immunostaining with anti-CYP19a1a (red). (E) Single immunostaining with anti-CYP11b (green). (B) Double immunostaining with anti-CYP11a (green) and anti-CYP19a1a (red). (D) Double immunostaining with anti-CYP11a (green) and anti-CYP11b (red). (F) Double immunostaining with anti-CYP11b (green) and anti-CYP19a1a (red). Nuclei were visualized with 4,'6-diamidine-2-phenylidole-dihydrochloride (DAPI, blue). White arrowhead indicates positive immunoreactivity. Scale bar shows 50 um. BV, blood vessel; OC, ovarian cavity.

(Takahashi et al., 1993). A. japonica CYP11b antibody reacted with a protein of about $40 \mathrm{kDa}$ in the ovary of Malabar grouper; this is similar molecular weight to the protein recognized in medaka, tilapia and toad, Xenopus laevis testes (Kobayashi et al., 1998). A. clarkii CYP19a1a antibody detected a protein approximately $56 \mathrm{kDa}$; this is similar molecular weight to that of other known fish CYP19a1a proteins (Kobayashi et al., 2010). These results suggesting that three antibodies could be used for present immunolocalization study.

Immunohistochemical analysis showed that CYP19a1a was localized in somatic cells surrounding germ cells. We previously reported that germ cells were distributed within the somatic tissue along the inner periphery of the ovarian cavity in the ovary of the Malabar grouper (Murata et al., 2009). CYP11b was localized in the cluster of somatic cells near the blood vessel in the dorsal side of the ovary. The immunoreactions against these two enzymes were not co-localized in any cells of the gonads. These results indicate that there are at least two types of SPCs, estrogen (E2) -producing cells and androgen (11KT) -producing cells in the ovary of this fish. Furthermore, the cells have different ultrastructures. Estrogen-producing cells had a small cytoplasmic volume with few organelles, as in fibroblasts. In contrast, androgen-producing cells had a large cytoplasmic volume with many large mitochondria, a structure typical of SPCs (Satoh 1974; Kanamori et al., 1985; Nakamura et al., 1993; Nakamura and Nagahama 1985). The timing of first appearance of these cells was also different. Estrogen-producing cells first appeared in undifferentiated gonads, while androgen-producing cells were first detected at the end of ovarian differentiation. These results strongly suggest that these two types of SPCs differentiate from somatic cells derived from different origins. This is the first report that estrogen (E2) and androgen $(11 \mathrm{KT})$ are produced in different cells in the gonads of teleost, and these cells have different origins.

Androgen-producing cells have been reported in the ovary tunica near the blood vessels in the protogynous honeycomb grouper Epinephelus merra (Alam et al., 2005). However, the origin of the androgen-producing cells had been remained mystery. Our study clarified the origin and development of this special cell. The immunohistochemical analysis indicated that CYP11a and CYP19a1a positive cells; estrogen-producing cells are distributed only surrounding gonial germ cells, and they are not appeared surrounding perinucleolus stage oocytes (Fig. 6). The meaning and function of this phenomenon and the role of E2 in the development of oocytes are still unclear. In future study, we would like to reveal these questions.

\section{Role of estrogen (E2) in ovarian differentiation}

Generally, it is accepted that E2 is essential for female sex differentaition in several vertebrates (Nakamura 2010). In the case of teleost fish, E2 also have important role in female sex differentiation (Hurk et al., 1982; Piferrer et al., 1994; Nakamura et al., 1998; Kitano et al., 2000; ljiri et al., 2008; Kobayashi et al., 2009); however, there are some reports that sex differentiation is not E2 dependent in fish (Satoh 1974; Kanamori etal., 1985). In the present study, we showed that CYP11a, a key enzyme in steroidogenesis, and CYP19a1a, essential for E2 production, are expressed in the
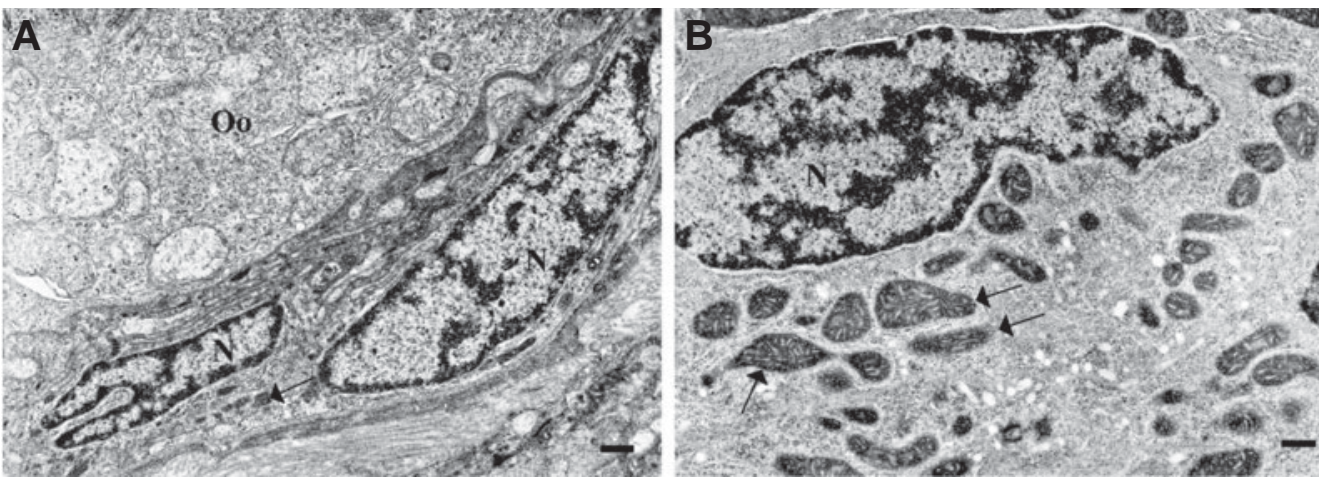
undifferentiated gonads and were present throughout ovarian differentiation in the protogynous Malabar grouper. Serum E2 was detectable during ovarian differentiation and was

Fig. 4. Ultrastructure of SPCs in the gonads of the Malabar grouper $(500$ DPH). (A) Ultrastructure of CYP19a1apositive cells surrounding germ cells. (B) Ultrastructure of CYP11b-positive cells near blood vessels. Oo: Oocyte. N Nucleus. Arrow indicates mitochondria. Scale bar, $500 \mathrm{~nm}$. 

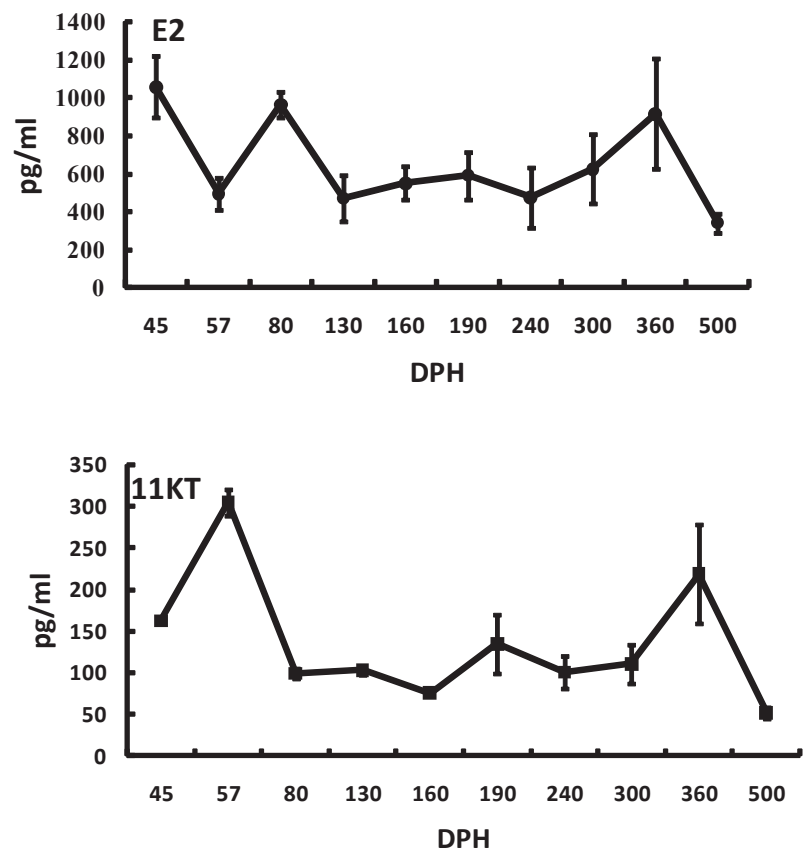

Fig. 5. Mean ( \pm SEM) serum 17beta-estradiol (E2) and 11-ketotestosterone $(11 \mathrm{KT})$ levels during ovarian differentiation and early ovarian development. $D P H$, days post-hatching.

present at higher levels than 11KT during ovarian differentiation and ovarian development. These results suggest that endogenous estrogen (E2) is produced in the gonads at the undifferentiated stage and may be involved in the initiation of ovarian differentiation. This is the first report about the involvement of E2 in the gonadal sex differentiation of protogynous hermaphroditic fish.

\section{Role of androgen (11KT) in ovarian differentiation and deve- lopment}

$11 \mathrm{KT}$ is fish specific androgen which plays a central role in male sexual maturation, in the development of secondary sexual characters, and in reproductive behavior (Borg, 1994). In Nile tilapia, mRNA

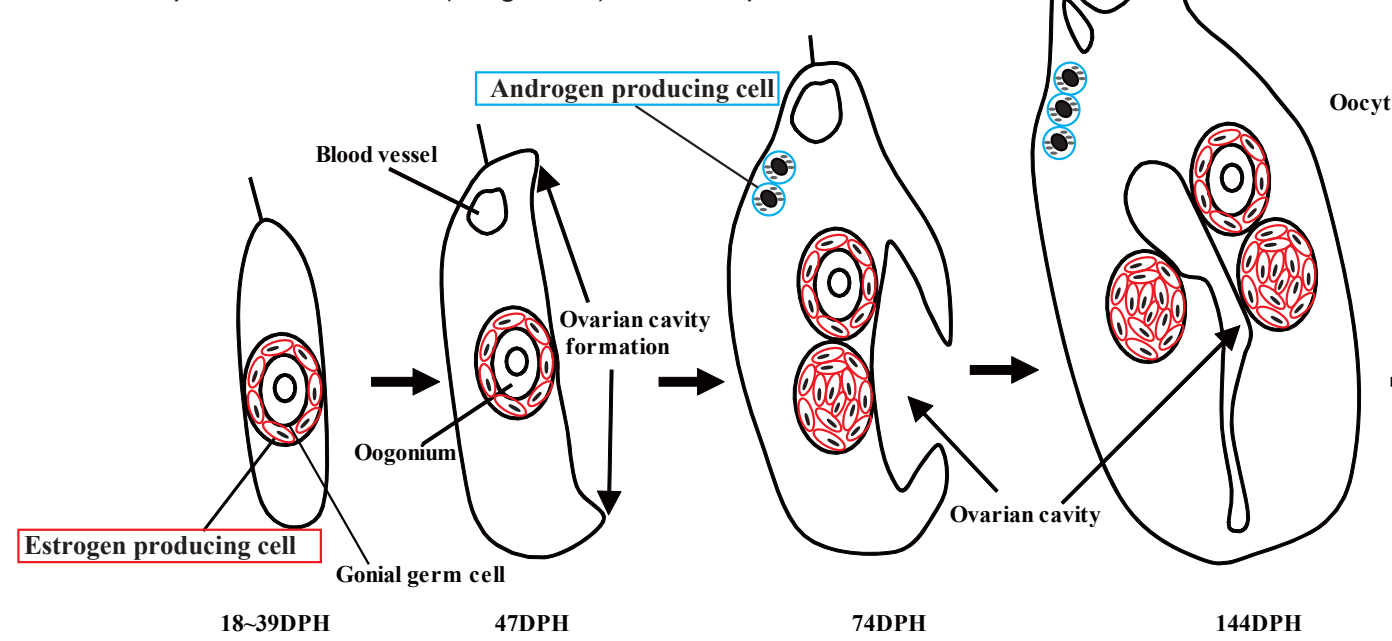

Undifferentiated

47DPH

Differentiation expression of CYP11b, which is involved in $11 \mathrm{KT}$ production, is not found in the ovary during ovarian differentiation and development. This observation suggested that $11 \mathrm{KT}$ is not synthesized in the gonads during undifferentiated stages and that it is not involved in ovarian differentiation (Nakamura et al., 1998; ljiri et al., 2008; Kobayashi et al., 2009). In this study, we showed that in the protogynous Malabar grouper, positive immunoreaction against CYP11b was not detected before or during ovarian differentiation, as it is in the Nile tilapia. However, immunoreaction against CYP11b was detected at the end of ovarian differentiation, and CYP11b-positive cells then appeared in the ovary tunica during ovarian development. In the protogynous honeycomb grouper E. merra, androgen-producing cells were also found in the ovary tunica near blood vessels; $11 \mathrm{KT}$ produced in the androgen-producing cells provides the stimulus for females to degenerate their oocytes and initiate sex change (Alam et al., 2005, 2006). Exogenous 11KT treatment can also induce a female-to-male sex change in the honeycomb grouper (Bhandari et al., 2006). Additionally, we recently reported that treatment with artificial androgen ( $17 \alpha$-methyltestosterone) caused a precocious female-to-male sex change in the Malabar grouper (Murata et al., 2010). On the basis of these findings, we hypothesize that CYP11bpositive cells in the ovary tunica of the juvenile Malabar grouper will also function to produce $11 \mathrm{KT}$ actively once the fish reaches a certain size or a sufficient age and will thereby stimulate female to male sex change. It is also possible that $11 \mathrm{KT}$ synthesized by CYP11b-positive cells in the gonads is involved in ovarian development. A previous report indicated that androgen plays a role in lipid accumulation in oocytes in the ovary of the short-finned eel Anguilla australis (Lockman et al., 2007). Although serum 11KT was detected during ovarian differentiation in our study, CYP11b expression was not detected in undifferentiated stages or during

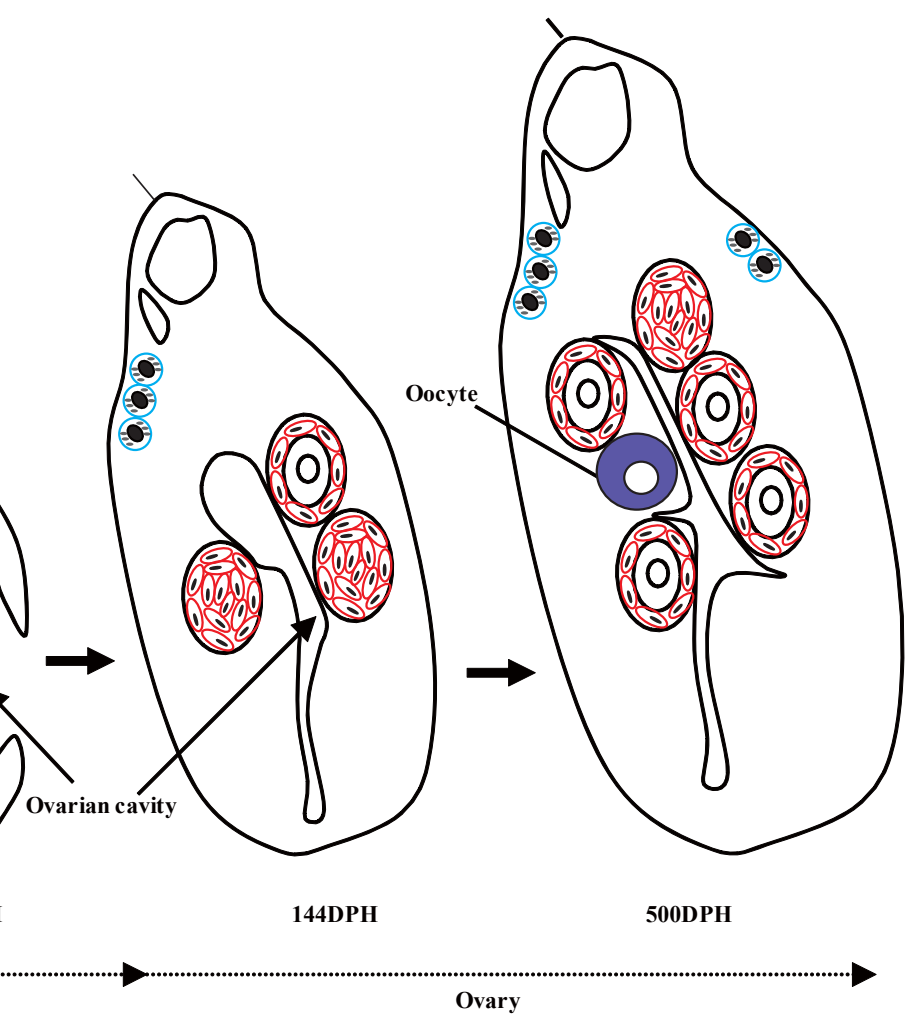

Fig. 6. Representation of the appearance of two types of steroid-producing cells (SPCs) in the gonads during ovarian differentiation. 
ovarian differentiation of the gonads. These results suggest that $11 \mathrm{KT}$ production does not originate in the gonads, but instead is produced in another organ prior to and during ovarian differentiation. While it is generally well known that steroid hormones are synthesized in various organs, such as the interrenal gland and the gonads, it is still unclear what role $11 \mathrm{KT}$ plays in ovarian differentiation and development in the Malabar grouper.

\section{Materials and Methods}

\section{Animals}

Specimens of E. malabaricus were raised in Okinawa prefectural Fisheries and Ocean Research Center, Ishigaki, Okinawa, Japan (Murata et al., 2009).

\section{Sampling procedures}

Prior to dissection, fish were anesthetized with $0.05 \%$ 2-phenoxyethanol. The gonads of six to seven fish were collected at $30,45,57,80$, $130,160,190,240,300,360$, and $500 \mathrm{DPH}$. The fish at $30 \mathrm{DPH}$ were too small to collect blood at. We collected blood samples from 50 to 70 fish by using capillary tubes $(45,57$, and $80 \mathrm{DPH})$ or a syringe (from 6 to 10 fish, 130 to $500 \mathrm{DPH}$ ). All animal handling and experimentation were conducted in accordance with our Guide for Care and Use of Laboratory Animals (animal-jikken-kisoku 19.6.26) and were approved by University of the Ryukyus.

\section{Western blotting}

SDS-PAGE and electroblotting were carried out as described in Kobayashi et al., (Kobayashi et al., 2010). For extraction of the gonadal proteins, the gonad of 3 years after-hatching fish were dissected and homogenized in SDS sample buffer. The gonadal proteins were separated by SDS-PAGE using SuperSepTMAce, 10-20\% gel (Wako, Japan), followed by CBBR staining or electrotransfer onto Immobilon-P, PVDF membrane (Millipore, Billerica, MA). Membranes were blocked by non-fat dried milk and then incubated with anti-Anguillajaponica CYP11a, CYP11b and anti-Amphiprion clarkii CYP19a1a antiserum diluted at 1:3000, 1:6000 and 1:6000 ratios, respectively, in tris-buffered saline containing $0.1 \%$ tween 20 (TTBS) for $2 \mathrm{~h}$. After washing with TTBS, membranes were incubated with 1:10000 diluted ZyMax, HRP conjugated goat anti-rabbit IgG (Zymed, Invitrogen). Peroxidase activity visualized by Renaissance chemiluminescence reagent (NEN, Boston, MA) was detected using LAS 3000 imager (Fujifilm, Japan).

\section{Immunohistochemistry}

We used three primary antibodies: the antibody $\alpha$-Anguilla japonica CYP11a and CYP11b was developed against $A$. japonica CYP11a and CYP11b enzyme (ljiri et al., 2006; Kobayashi et al., 1998). The antibody $\alpha$-Amphiprion clarkiiCYP19a1a was developed against $A$. clarkiiCYP19a1a enzyme (Kobayashi et al., 2010). The specificity of eel steroidogenic enzyme antibody against grouper was already confirmed by Alam et al., 2005. Clownfish Cyp19 fell into the phylogenetic cluster of Cyp19a1a with grouper (Kobayashi et al., 2010).

The gonads were fixed with Bouin's solution for approximately $12 \mathrm{~h}$ and transferred to $70 \%$ ethanol for storage. Later, fixed gonads were dehydrated, embedded in paraffin, and sectioned at $5 \mu \mathrm{m}$. In order to immunolocalize CYP11a, CYP19a1a, and CYP11b in ovarian tissues, $5 \mu \mathrm{m}$ gonad sections were deparaffinized with xylene, rehydrated in graded alcohols, and finally washed in phosphate-buffered saline (PBS). They were then treated with $3 \%$ $\mathrm{H}_{2} \mathrm{O}_{2}$ for 15 min to inactivate endogenous peroxidase activity. To eliminate non-specific binding, slides were incubated with $10 \%$ normal goat serum for $15 \mathrm{~min}$. They were incubated overnight with the primary antibodies (diluted 1:2000-1:3000 in 1\% BSA/PBS) in a moist chamber at $4^{\circ} \mathrm{C}$. The detection and visualization of primary antibodies was completed using the Histofine $\alpha$-rabbit immunohistochemistry kit from Nichirei (Tokyo, Japan) and diaminobenzidine (DAB).

\section{Fluorescent immunohistochemistry}

To address whether CYP19a1a co-localizes with CYP11b in the same somatic cells, the gonads were fixed with $4 \%$ paraformaldehyde (PFA) in PBS at $4^{\circ} \mathrm{C}$ overnight, washed twice with PBS ( 1 hour per wash), then transferred to $70 \%$ ethanol for storage at $4^{\circ} \mathrm{C}$. Later, fixed gonads were dehydrated, embedded in paraffin, and sectioned at $5 \mu \mathrm{m}$. We also used three primary antibodies, which were the same as those used in the immunohistochemistry experiments. The gonad sections were deparaffinized, and slides were incubated with $10 \%$ BSA in PBS for 30 min to eliminate non-specific binding. They were immediately incubated with the first primary antibodies (diluted 1:1000-1:2000 in 1\% BSA/PBS) for 3 hours, washed three times with PBS (each $3 \mathrm{~min}$ ), incubated with $10 \% \mathrm{BSA} /$ PBS for $30 \mathrm{~min}$, and then incubated for $30 \mathrm{~min}$ with anti-rabbit-IgG-Alexa 488 (Invitrogen)-conjugated antibody in the dark. The slides were washed three times with PBS (each $3 \mathrm{~min}$ ), incubated with 10\% BSA/PBS for 30 min, and subsequently incubated with second primary antibodies (diluted $1: 1000-2000$ in $1 \% \mathrm{BSA} / \mathrm{PBS})$ overnight at $4^{\circ} \mathrm{C}$ in the dark. Later, the slides were washed three times with PBS (each $3 \mathrm{~min}$ ), incubated with $10 \%$ BSA/PBS for $30 \mathrm{~min}$, and incubated for $30 \mathrm{~min}$ with anti-rabbit-IgGAlexa 568(Invitrogen)-conjugated antibody in the dark. The slides were then washed three times with PBS (each $3 \mathrm{~min}$ ) and mounted in glycerin containing DAPI (ProLong Gold antifade reagent with DAPI; invitrogen).

\section{Ultrastructural observation of immunoreactive cells}

We observed the ultrastructure of steroidogenic enzyme-positive cells as described by Nakamura and Nagahama 1985.

\section{Measurement of steroid hormones}

Serum E2 and 11KT were quantified by enzyme-linked immunosorbent assay (ELISA) as described by Asahina et al., 1995.

\section{Statistics}

All data were expressed as mean \pm SEM. One-way analysis of variance (ANOVA) followed by a Tukey-Kramer comparison test, was used for statistical analysis of serum E2 and $11 \mathrm{KT}$ levels.

\section{Acknowledgements}

We are grateful to Dr. Paul V. Dunlap at the University of Michigan for critical reading of the manuscript. Grant support:The present work was supported by grant for the solution-oriented research for science and technology (SORST) and Ocean Exposition commemorative Park management Foundation.

\section{References}

ALAM MA, BHANDARI RK, KOBAYASHI Y, SOYANO K, NAKAMURA M (2006). Changes in androgen-producing cell size and circulating 11-ketotestosterone levels during female-to-male sex change in honeycomb grouper (Epinephelus merra). Mol Replod Dev 73: 206-214.

ALAM MA, KOMURO H, BHANDARI RK, NAKAMURA S, SOYANO K, NAKAMURA $M$ (2005). Immunohistochemical evidence identifying the site of androgen production in the ovary of the protogynous grouper Epinephelus merra. Cell Tissue Res 320: 323-329.

ASAHINA K, KAMBEGAWAA, HIGASHI T (1995). Development of a microtiter plate enzyme-linked immunosorbent assay for 17 $\beta$-21-trihydroxy-4-pregnen-3-one, a teleost gonadal steroid. Fish Sci 61: 491-494.

BHANDARI RK, ALAM MA, SOYANO K, NAKAMURAM (2006). Induction of femaleto-male sex change in the honeycomb grouper (Epinephelus merra) by 11-ketotestosterone treatments. Zool Sci 23: 65-69.

BHANDARIRK, KOMUROH, NAKAMURAS, HIGAM, NAKAMURAM (2003). Gonadal restructuring and correlative steroid hormone profiles during natural sex change in protogynous honeycomb grouper (Epinephelus merra). Zool Sci 20: 1399-1404.

BORG B (1994) Androgens in teleost fishes. Comp Biochem Physiol C 109: 219-245.

BRUSLE-SICARD S, DEBAS L, FOURCAULT B, FUCHS J (1992). Ultrastructural study of sex inversion in a protogynous hermaphrodite, Epinephelus microdon 
(Teleostei, Serranidae). Reprod Nutr Dev 32: 393-406.

GRISWOLD SL, BEHRINGER RR (2009). Fetal Leydig cell origin and development. Sex Dev 3: 1-15.

HABERT R, LEJEUNE H, SAEZ JM (2001). Origin, differentiation and regulation of fetal and adult Leydig cells. Mol Cell Endocrinol 179: 47-74.

HOAR WS, NAGAHAMA Y (1978). The cellular sources of sex steroids in teleost gonads. Ann Biol Anim Biochem Biophys 18: 893-898.

IIJIRI S, KANEKO H, KOBAYASHI T, WANG D, SAKAI F, PAUL B, NAKAMURA M, NAGAHANA Y (2008). Sexual dimorphic expression of genes in gonads during early differentiation of a teleost fish, the Nile Tilapia Oreochromis niloticus. Biol Replod 78: 333-341.

IJIRI S, TAKEI N, KAZETO Y (2006). Changes in localization of cytochrome P450 cholesterol side-chain cleavage (P450scc) in Japanese eel testis and ovary during ganadal development. Gen Comp Endocrinol 145: 75-83.

KAGAWA H, YOUNG G, ADACHI S, NAGAHAMA Y (1982). Estradiol-17 $\beta$ production in amago salmon (Oncorhynchus rhodurus) ovarian follicles: Role of the thecal and granulosa cells. Gen Comp Endocrinol 47: 440-448.

KANAMORIA, NAGAHAMAY, EGAMIN (1985). Development of the tissue architecture in the gonads of the Medaka Oryzias latipes. Zool Sci 2: 695-706.

KIME DE (1993). Classical and non-classical reproductive steroids in fish. Rev Fish Biol 3: 160-180.

KITANO T, TAKAMUNE K, NAGAHAMA Y, ABE S. 2000. Aromatase inhibitor and 17alpha-methyltestosterone cause sex-reversal from genetical females to phenotypic males and suppression of $P 450$ aromatase gene expression in Japanese flounder (Paralichthys olivaceus). Mol Reprod Dev 56: 1-5.

KOBAYASHI T, KOBAYASHI HK, NAGAHAMA Y (1998). A novel stage-specific antigen is expressed only in early stages of spermatogonia in Japanese eel,Anguilla japonica testis. Mol Reprod Dev 51: 355-361.

KOBAYASHI T, NAGAHAMA Y (2009). Molecular Aspects of Gonadal Differentiation in a Teleost Fish, the Nile Tilapia. Sex Dev 3: 108-117.

KOBAYASHI T, NAKAMURA M, KAJIURA-KOBAYASHI H, YOUNG G, NAGAHAMA $Y$ (1998). Immunolocalization of steroidogenic enzymes (P450scc, P450c17, $\mathrm{P} 450$ arom, and $3 \beta$-HSD) in immature and mature testes of rainbow trout (Oncorhynchus mykiss). Cell Tissue Res 292: 573-577.

KOBAYASHI Y, HORIGUCHI R, MIURA S, NAKAMURA M (2010). Sex- and tissuespecific expression of P450 aromatase (cyp19a1a) in the yellowtail clownfish, Amphiprion clarkia. Comp Biochem Physiol A 155: 237-244.

LOKMAN PM, GEORGE KNA, DIVERS SL, ALGIE M, YOUNG G (2007). 11-ketotestosterone and IGF-1 increase the size of previtellogenic oocytes from shortfinned eel, Anguilla australis, in vitro. Reploduction 133: 955-967.

MAGOFFIN DA (2005). Ovarian theca cell. Int J Biochem Cell Biol 37: 1344-1349.

MILLER WL (1988). Molecular biology of steroid hormone synthesis. Endocrinol Rev 9: 295-318.

MIURA T, YAMAGUCHI K, TAKAHASHI H, NAGAHAMA Y (1991). Hormonal induction of all stages of spermatogenesis in vitro in the male Japanese eel (Anguilla japonica). Proc Natl Acad Sci USA 88: 5774-5778

MURATAR, KARIMATAH, ALAM MA, NAKAMURAM (2009). Gonadal sex differentiation in the Malabar grouper, Epinephelus malabaricus. Aquaculture 293: 286-289.

MURATAR, KARIMATAH, ALAM MA, NAKAMURAM (2010). Precocious sex change and spermatogenesis in the underyearling Malabar grouper Epinephelus malabaricus by androgen treatment. Aquaculture research 41: 303-308.

NAGAHAMA Y, KAGAWA H, YOUNG G (1982). Cellular sources of sex steroids in teleost gonads. Can J Fish Aquat Sci 39: 56-64.

NAKAMURA M (2010). The mechanism of sex determination in vertebrates-Are sex steroids the key-factor? J Exp Zool 313A: 381-398.

NAKAMURA M, JENNIFER LS, NAGAHAMA Y (1993). Ultrastructural analysis of the developing follicle during early vitellogenesis in tilapia, Oreochromis niloticus, with special reference to the steroid-producing cells. Cell Tissue Res 272:33-39.

NAKAMURAM, JENNIFERLS, NAGAHAMAY (1996). Innervation of steroid-producing cells in the ovary of tilapia Oreochromis niloticus. J Zool Sci 13: 603-608.

NAKAMURA M, KOBAYASHI T, CHANG XT, NAGAHAMA Y (1998). Gonadal sex differentiation in teleost fish. $J$ Exp Zool 281: 362-372.

NAKAMURAM, NAGAHAMAY (1985). Steroid producing cells during ovarian differentiation of the Tilapia, Sarotherodon niloticus. Dev. Growth Differ 27 (6): 701-708

NAKAMURA M, NAGAHAMA Y (1989). Differentiation and development of Leydig cells, and changes of testosterone levels during testicular differentiation in tilapia Oreochromis niloticus. Fish Physiol Biochem 7: 211-219.

NAKAMURAM, NAGAHAMAY (1993). Ultrastructural study on the differentiation and development of steroid-producing cells during ovarian differentiation in the amago salmon, Oncorhynchus rhodurus. Aquaculture 112: 237-251.

PIFERRER F, DONALDSON EM (1994). Uptake and clearance of exogenous estradiol-17 beta and testosterone during the early development of coho salmon (Oncorhynchus kisutch), including eggs, alevins and fry. Fish Physiol Biochem 13: 219-232.

SADOVY Y, COLIN PL (1995). Sexual development and sexuality in the Nassau grouper. J Fish Biol 46: 961-976.

SATOH N (1974). An ultrastructural study of sex differentiation in the teleost Oryzias latipes. J Embryol Exp Morphol 32: 192-215.

SCHMAHLJ, RIZZOLOK, SORIANO P (2008). The PDGF signaling pathway controls multiple steroid-producing lineages. Genes Dev 22: 3255-3267.

SHAPIRO DY (1987). Differentiation and evolution of sex change in fishes. Bioscience 37:490-496.

SHAPIRO DY, SADOVY Y, MCGEHEE MA (1993). Periodicity of sex change and reproduction in the red hind, Epinephelus guttatus, a protogynous grouper. Bull Mar Sci 53: 1151-1162.

SMITH CL (1965). The patterns of sexuality and the classification of serranid fishes. Am Mus Novit 2207: 1-20.

TAKAHASHI M, TANAKAM, SAKAIN, ADACHIS, MILLERWL, NAGAHAMAY (1993). Rainbow trout ovarian cholesterol side-chain cleavage cytochrome P450 (P450scc) cDNA cloning and mRNA expression during oogenesis. FEBS Lett 19: 45-48.

TAN SM, TAN KS (1974). Biology of the tropical grouper, Epinephelus tauvina (Forskal). I: A preliminary study on hermaphroditism in E. tauvina. Singap J Prim Ind 2: 123-133.

VAN DEN HURK R, LAMBERT JGD, PEUTE J (1982). Steroidgenesis in the gonads of rainbow trout fry (Salmo gairdneri) before and after the onset of gonadal sex differentiation. Replod Nutr Dev 22: 413-425.

ZHOU L, GUI JF (2010). Molecular mechanisms underlying sex change in hermaphroditic groupers. Fish Physiol Biochem 36: 181-193. 


\section{Further Related Reading, published previously in the Int. J. Dev. Biol.}

Identification of side population cells in mouse primordial germ cells and prenatal testis

Maria-Lucia Scaldaferri, Stefania Fera, Laura Grisanti, Massimo Sanchez, Mario Stefanini, Massimo De Felici and Elena Vicini Int. J. Dev. Biol. (2011) 55: 209-214

A polymorphic, thrombospondin domain-containing lectin is an oocyte marker in Hydractinia: implications for germ cell specification and sex determination

Brahim Mali, R. Cathriona Millane, Günter Plickert, Marcus Frohme and Uri Frank

Int. J. Dev. Biol. (2011) 55: 103-108

Role of fetal membranes in signaling of fetal maturation and parturition

Leslie Myatt and Kang Sun

Int. J. Dev. Biol. (2010) 54: 545-553

Estrogenic in vitro assay on mouse embryonic Leydig cells

Gina La Sala, Donatella Farini and Massimo De Felici

Int. J. Dev. Biol. (2010) 54: 717-722

Development and function of trophoblast giant cells in the rodent placenta

Dong $\mathrm{Hu}$ and James $\mathrm{C}$. Cross

Int. J. Dev. Biol. (2010) 54: 341-354

Neurogenic and mitotic effects of dehydroepiandrosteroneon neuronal-competent marrow mesenchymal stem cells

Esmaeil H. Shiri, Narges-Zare Mehrjardi, Mahmood Tavallaei, Saeid K. Ashtiani and Hossein Baharvand

Int. J. Dev. Biol. (2009) 53: 579-584

The developing female genital tract: from genetics to epigenetics

Julie Massé, Tanguy Watrin, Audrey Laurent, Stéphane Deschamps, Daniel Guerrier and Isabelle Pellerin

Int. J. Dev. Biol. (2009) 53: 411-424

Instructive roles for hormones in plant development

David Alabadí, Miguel A. Blázquez, Juan Carbonell, Cristina Ferrándiz and Miguel A. PérezAmador

Int. J. Dev. Biol. (2009) 53: 1597-1608

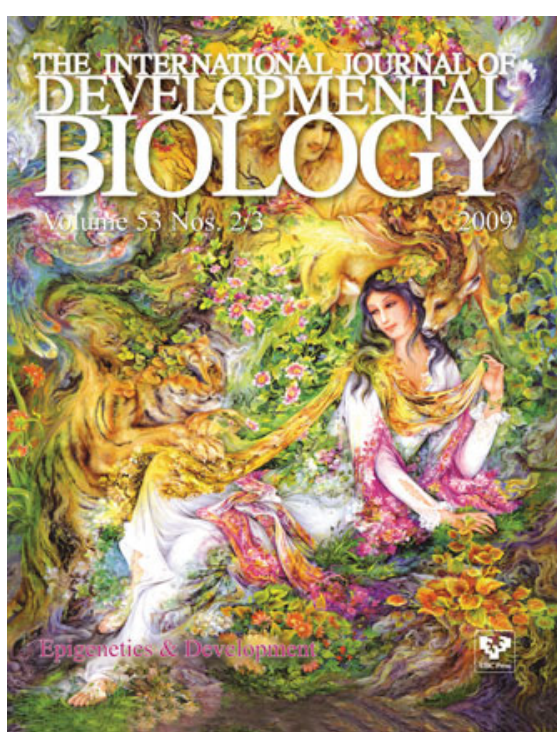

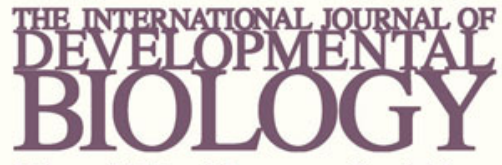

Volume 54 Nos. $6 / 7$
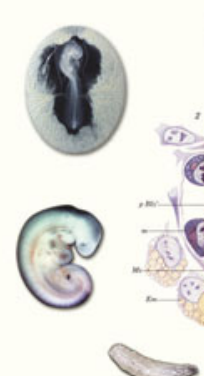

Developmental Hematopoiesis
ISI Impact Factor $(2010)=2.86$
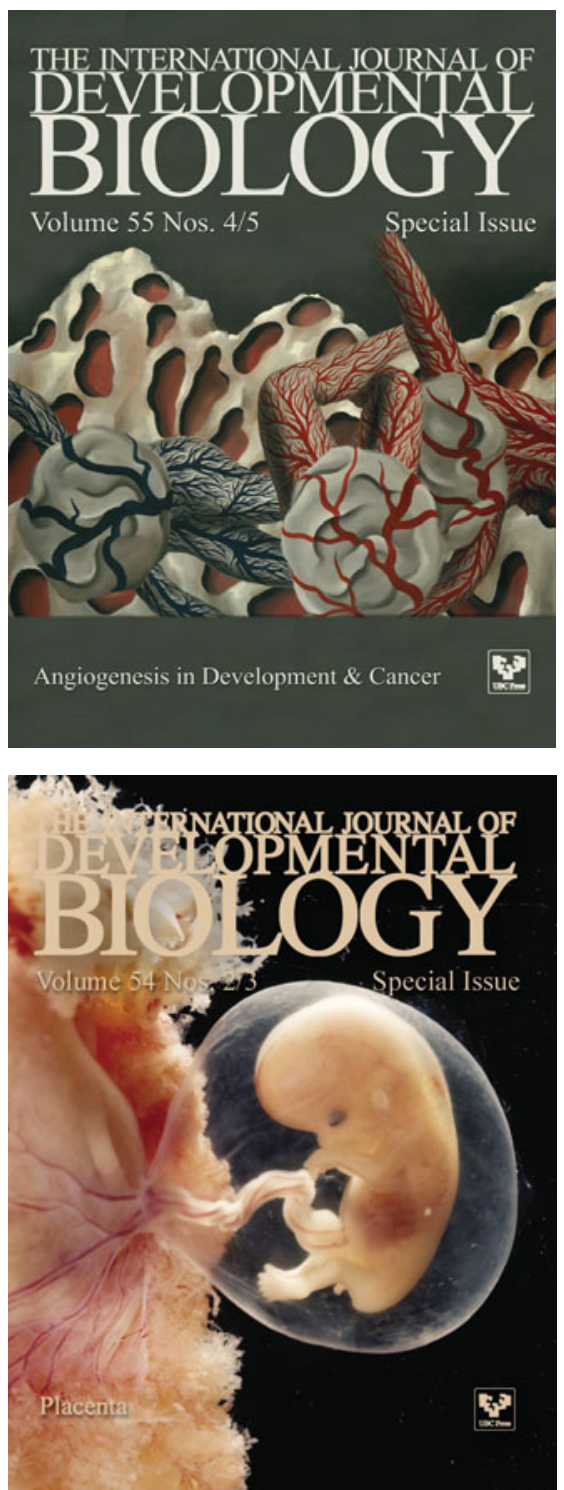